\title{
Land and Water Carrying Capacity in Tourism Area of Nusa Penida, Bali
}

\author{
Nyoman Sudipa $^{1 *}$, Made Sudiana Mahendra ${ }^{2}$, Wayan Sandi Adnyana ${ }^{3}$ Ida Bagus Pujaastawa \\ ${ }^{1}$ Environmental Sciences Study Program Udayana University. PB. Sudirman Street, Denpasar. Bali. \\ ${ }^{2}$ Environmental Sciences Study Program Udayana University \\ ${ }^{3}$ Environmental Sciences Study Program Udayana University \\ ${ }^{4}$ Culture Sciences Study Program Udayana University
}

\begin{abstract}
Environmental resources are very important in supporting tourism activities. As a developing tourism area Nusa Penida needs sufficient land and water resources. Increasing population of residents and tourists triggers new activities that affect the patterns of land use and available water, which in turn has a negative impact on the availability of land and water. The carrying capacity of the environment is disrupted due to the utilization of environmental resources that exceed its capacity. This study aims to calculate the availability, needs and status of the carrying capacity of land and water in the Nusa Penida Tourism Area. The methodology of this study is to calculate the availability of land and water, calculate land and water needs for residents and tourists and calculate the carrying capacity of land and water. This study predicts the availability of land and water, land and water needs and the carrying capacity of land and water in the Nusa Penida Tourism Area until 2023.

From the results of data analysis shows that the availability of land in Nusa Penida amounted to 5,350 hectares. Projected land needs until the year 2028 of 24,640 hectares, the carrying capacity of the land in Nusa Penida deficit. The results of the calculation of land requirements based on the ecological footprint amounted to $17,724.283$ hectares, while the availability of land in Nusa Penida was 5,350 hectares. This shows that the carrying capacity of the land in Nusa Penida has a deficit of 12,374,283 hectares.

Availability of water based on rainfall and springs in Nusa Penida is $95,443,402.56 \mathrm{~m}^{3} /$ year. The results of data analysis show that in 2028 water needs for residents and tourists are estimated at $83,398,400 \mathrm{~m}^{3} /$ year. Projection of the carrying capacity of water in Nusa Penida based on rainfall surplus of $901,002.56 \mathrm{~m}^{3} /$ year. Projection of the carrying capacity of water in Nusa Penida based $10 \%$ utilization of springs Penida and Guyangan in 2028 surplus of 2,433,865,856.44 $\mathrm{m}^{3} /$ year Projection of the carrying capacity of water in Nusa Penida based on rainfall $+10 \%$ utilization of springs Penida and Guyangan in 2023 surplus of $2,529,309,259 \mathrm{~m}^{3} /$ year. Projection of the carrying capacity of water in Nusa Penida based on rainfall + all springs water potencyin Nusa Penida in 2028 surplus of 34,958,390,240 $\mathrm{m}^{3} /$ year.
\end{abstract}

Keywords: Tourism, Carrying Capacity, Land, Water, Availability, Needs, Status, Nusa Penida

\section{Introduction}

The development of tourism in the last three years in Nusa Penida has increased rapidly. In 2016, the number of tourists coming to Nusa Penida was 350,000 and it is predicted that in 2025 it will reach 1,050,000 (KSPN, 2016). Exceeds tourism increase. In 2016 the total number of 189 and the total number of 1300 and in 2017 the total number increased by 301 and the number of rooms by 2143 . Increasing the number of tourists to the environment and increasing carrying capacity the environment supports the carrying capacity of the land and water, so that every growth supports tourism, tourists and population growth need land and water carrying capacity to support the sustainability of tourism.

The increasing population participating in activities related to available water use patterns, which are present at the time associated with negative impacts on related water can also affect the environment that supports the carrying capacity of the environment to protected air (Admadhani et al., 2014). 
Tourism industry activities are inseparable from the need for land and water. In the tourism industry activities. Land is used for building activities, green open space and water is used for MCK activities, laundry, kitchen / restaurant activities, and garden activities (hotel landscapes).

The carrying capacity of land and water is calculated by considering the availability and need for water resources for residents and tourists in the study area. To measure the magnitude of environmental degradation, it is necessary to have an inventory of natural resources. Measurement of environmental degradation will give an idea of how much the environment is able to support human life (Wijaya et al., 2017). land carrying capacity is systematic land use and population data (Riyadi and Bratakusumah, 2004). Decreased carrying capacity of land has a negative effect due to the conversion of land into other allotments due to the growth of urbanization (Qian et al., 2015). Analysis of the carrying capacity of agricultural land needs to be done to determine the ability of land to provide food to meet the needs of the population in a certain area and time (Moniaga, 2011). The availability of water for the population shows an indicator of the carrying capacity of water for the environment, especially for the population and all their life activities. Water carrying capacity includes aspects of meeting water needs and availability (Santoso, 2015). Decreased water carrying capacity due to lack of water resources, serious water pollution, and low water use efficiency (Lu et al., 2017). As an economic entity, water resources must be managed as economic goods through the principles of sustainable environmental resource management (Asdak et al., 2006).

This study aims to determine the availability of land, land requirements and carrying capacity of land and determine the availability of water both from rainfall, springs and groundwater reserves, water needs for residents and tourists and determine the status of water carrying capacity in the Nusa Penida Tourism Area.

\section{Experimental Method}

\section{Land Carrying Capacity}

\section{- Calculation of Land Availability}

Calculation of land availability was done by calculating the availability of land. Analysis of land availability using equations that refer to the Minister of Environment Regulation No. 17 of 2009 as follows:

$$
\mathrm{S}_{\mathrm{L}}=\frac{\Sigma(\mathrm{Pi} \times \mathrm{Hi})}{H b} \chi \frac{1}{\text { Ptvb }}
$$

SL is the availability of land, $\mathrm{Pi}$ is the actual production of each type of commodity (the unit depends on the type of commodity). Commodities calculated include agriculture, plantation, forestry, animal husbandry and fisheries, Hi is the unit price of each type of commodity ( $\mathrm{Rp} /$ unit) at the producer level, $\mathrm{Hb}$ is the unit price of rice $(\mathrm{Rp} / \mathrm{kg})$ at the producer level and Ptvb rice productivity ( $\mathrm{Kg} / \mathrm{Ha})$. In this calculation, the conversion factor is used to equalize non-rice products is price.

\section{- Calculation of Land Requirements}

To find out whether there is sufficient land inventory can be done by comparing the amount of available land with the land requirements. The equation used refers to Minister of the Environment Regulation No. 17 of 2009:

$\mathrm{DL}=\mathrm{N} \times \mathrm{KHLL}$

DL is the total land requirement equivalent to rice (Ha), $\mathrm{N}$ is the number of residents (people) and KHLL is the area of land needed for the needs of decent living per resident and tourist needs.

\section{- Determination of Land Carrying Capacity Status}

The carrying capacity of land was obtained by comparing the availability of land (SL) and land requirements (DL) (Minister of Environment Regulation No. 17 of 2009):

If SL> DL, the carrying capacity of the land is declared surplus.

If SL <DL, carrying capacity is declared deficit or exceeded.

\section{Capacity of Land based on Ecological Footprint}

The ecological footprint calculation in this study adopted using the ecological footprint calculation used by the Global Footprint Network (GFN). The calculation of the ecological footprint considers the six parts of basic necessities products expressed in the form of agricultural, livestock, forest, fishery products, built-up areas, and energy use, where each staple product has global average yields and equivalent factors (Adnyana 
et al., 2011). Equations to calculate the ecological footprint for types of agricultural products, livestock, forests, fisheries, and built areas are:

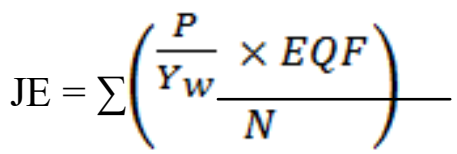

information:

$\mathrm{JE}=$ ecological footprint (gha / capita)

$\mathrm{P}=$ total consumption of each type of product (tonnes or $\mathrm{m} 3$ )

$\mathrm{Yw}=$ global average yield factor (ton $/ \mathrm{ha}$ )

$\mathrm{EQF}=$ equivalent factor $(\mathrm{gha})$

$\mathrm{N}=$ population

The equation for calculating the ecological footprint of the type of product built area is:

\section{Built Area = Area XB x YW x EQF}

information:

JEArea Awakened = ecological footprint (gha / capita)

Size $=$ total area developed (ha)

$\mathrm{XB}=$ coefficient value $(2,368 \times 10-8)$

$\mathrm{Yw}=$ global average yield factor (ton $/$ ha)

$\mathrm{EQF}=$ equivalent factor (gha)

The ecological footprint of energy use is calculated by the equation:

$\mathrm{JE}$ Use of Energy $=\mathrm{C} \times\left(\frac{1-f a O c}{Y c}\right) \times \mathrm{c}$

information:

JEPeng use of Energy = The ecological footprint of energy use (gha / capita)

$\mathrm{C}=$ consumption of fossil fuels and electricity (tons)

$\mathrm{faOc}=\mathrm{CO}$ absorbed by the sea $(0.27 \mathrm{CO} 2 / \mathrm{gha})$

$\mathrm{Yc}=$ Sequestration rate $(1.35$ tons $/ \mathrm{gha})$

$\mathrm{c}=$ coefficient value $(1.18 \times 10-8)$

The equivalent factor is a conversion factor from the broad dimension (ha) to the global broad dimension (gha). The equivalent factor is the same for each country and does not change. The equivalent factor values can be seen in Table 1 .

Table 1. Equivalent Factor Values

\begin{tabular}{|l|c|}
\hline \multicolumn{1}{|c|}{ Basic Products } & Equivalent Factor (gha) \\
\hline Agriculture & 2.64 \\
\hline Animal Husbandry & 0.50 \\
\hline Forest & 1.33 \\
\hline Fishery & 0.40 \\
\hline Built area & 2.64 \\
\hline Used energy & 1.00 \\
\hline
\end{tabular}

Calculation of land needs based on guidelines for determining the carrying capacity of land carrying capacity for water (KLH, 2008) at level 3. Calculation of land needs at level 3 includes the influence of JE values in its calculations. The equations for calculating land requirements at level 3 are:

$\mathrm{DL}=\mathrm{N} \times \mathrm{JE}$

information:

$\mathrm{DL}=$ total land requirements

$\mathrm{N}=$ total population (people) 
$\mathrm{JE}=$ ecological footprint (gha /capita)

\section{Water Supply Capacity}

\section{- Calculation of Water Availability}

Calculation of Weighted Runoff Coefficient. There are 2 types of land use in the study area, namely agricultural land and non-agricultural land. For agricultural land consisting of paddy land with a runoff coefficient range $(\mathrm{Ci})$ around 0.30 , non-paddy land with runoff coefficient 0.30 , and non-agricultural land with a coefficient of $0.15-0.9$ (Pramesty et al., 2014). Calculation of the weighted runoff coefficient is presented in Table 2.

Table 2. Calculation of Weighted Runoff Coefficient

\begin{tabular}{|l|l|c|}
\hline No & \multicolumn{1}{|c|}{ Surface Description } & Runoff Coefficient \\
\hline \multicolumn{2}{|l|}{ gricultural Land } & \\
\hline iddy Field & - \\
\hline 1 & echnical Irrigation & 0.3 \\
\hline 2 & alf Technical Irrigation & 0.3 \\
\hline 3 & imple Irrigation & - \\
\hline 4 & illage Irrigation & 0.3 \\
\hline 5 & ainfed & - \\
\hline 6 & idal & - \\
\hline 7 & bbak & - \\
\hline 8 & ther Polder and Rice Field & \\
\hline on Rice Field & 0.3 \\
\hline 1 & arden & 0.3 \\
\hline 2 & eld & 0.3 \\
\hline 3 & antation & 0.3 \\
\hline 4 & ree/Community Forest Planted & - \\
\hline 5 & pnd & 0.3 \\
\hline 6 & pol/Grass & - \\
\hline 7 & asture/Grassland & 0.3 \\
\hline 8 & hile Not Attempted & 0.3 \\
\hline 9 & ther & 0.15 \\
\hline on Agriculture Land & 0.18 \\
\hline 1 & he Yard Not Planted & 0.2 \\
\hline 2 & prest State & 0.9 \\
\hline 3 & wamps (Not Planted) & \\
\hline 4 & ther & \\
\hline
\end{tabular}

Source: Premesty et al., 2016

Calculation of water availability using the runoff coefficient method is modified by the rational method. The equation for calculating water availability is the runoff coefficient method (Minister of Environment Regulation No. 17 of year 2009) as follows:

$\mathrm{S}_{\mathrm{A}}=10 \times \mathrm{C} \times \mathrm{R} \times \mathrm{A}$

$\mathrm{SA}$ is the availability of water (m3/yr), $\mathrm{C}$ is the weighted runoff coefficient, $\mathrm{R}$ is the average yearly rainfall ( $\mathrm{mm} / \mathrm{yr}$ ), A is the area (ha), and 10 is a conversion factor from $\mathrm{mm} / \mathrm{ha}$ to $\mathrm{m} 3$ Besides that, the availability of water from existing springs, because in Nusa Penida there are 2 springs that have been utilized. $\mathrm{C}$ value is the average value of runoff coefficient in an area.

$\mathrm{C}=\frac{\Sigma(\mathrm{Ci} \times \mathrm{Ai})}{\Sigma_{\mathrm{Ai}}}$

$\mathrm{Ci}$ is the land use runoff coefficient $\mathrm{i}$, while $\mathrm{Ai}$ is the land use area $\mathrm{i}$.

$\mathrm{R}=\Sigma \frac{\mathrm{Ri}}{\mathrm{m}}$ 
Average annual rainfall algebra is obtained based on the comparison of annual rainfall ( $\mathrm{Ri}$ ) to the number of rainfall observation stations $(\mathrm{m})$.

\section{- Population Projection}

In the calculation of population projections that are used to determine the amount of water needs for the next 10 years using calculations with exponential methods. The calculation of the exponential projection method can be done using the equation:

$\mathrm{Pn}=$ Po.er.n

information:

Pn $=$ Projection of population in the desired year

Po $=$ Number of population in the last available data

$\mathrm{r}=$ Population growth rate

$\mathrm{n}=$ time period in years

$\mathrm{e}=$ Exponential number $=2.7182818$

\section{- Water needs for tourism}

Water carrying capacity is calculated by considering the availability and need for water resources for residents and tourists in the study area. Water availability is determined using the runoff coefficient method based on land use information and annual rainfall data calculated for 10 years. Meanwhile, water needs are calculated from the results of conversion to the needs of decent living of residents and tourists (Sunarta, 2015). Determination of water carrying capacity is done by comparing the availability and demand of water. Water needs for the Falkenmark indicator population which is the minimum water requirement to be able to live properly based on estimates of domestic, industrial and energy water needs, as well as environmental needs, where for Indonesia the value is set at 1,600 m3 / capita / year (Minister of Environment Regulation No. 17 of 2009) and for tourism in Nusa Penida using the basic needs of decent living tourists and restaurants that have been built in Nusa Penida in the last year. The average amount of water usage per day in accordance with the Planning Criteria of the Directorate General of Human Settlements of the Public Works Department in 1996 was 150 liters per person / bed and 100 liters restaurant per seat.

\section{- Calculation of Water Demand}

Water demand analysis using equations that refer to the Minister of Environment Regulation No. 17 of Year 2009:

$\mathrm{D}_{\mathrm{A}}=\mathrm{N} \times \mathrm{KHL}_{\mathrm{A}}$

DA is the total water demand ( $\mathrm{m} 3 / \mathrm{yr}$ ), $\mathrm{N}$ is the number of residents (people) and tourists, and KHLA is an Falkenmark indicator which is the minimum water requirement to be able to live properly based on estimates of domestic, industrial and energy water needs, as well as the needs environment, where for Indonesia the value is set at 1,600 m3 / capita / year (Minister of Environment Regulation No. 17 of 2009). Besides that, Nusa Penida also needs water for tourism purposes, assuming per capita consumption per day from the number of tourists who come.

\section{- Determination of the Water Carrying Capacity Status}

Water carrying capacity is obtained from a comparison between the availability of water (SA) and water demand (DA) with the condition if SA> DA, then the carrying capacity of water is declared surplus, if SA $<\mathrm{DA}$, then the carrying capacity of water is declared deficit or exceeded.

\section{Result And Discussion}

\section{Land}

Land area in Nusa Penida according to land use is mostly non-paddy land area of 14,366 ha. Non-rice fields are mostly tegal / gardens covering an area of 4,970 ha, plantations 3,572 ha. Planted a tree area of 5,361 Ha. Nusa Penida has 1,048 Ha of state forest consisting of $824 \mathrm{Ha}$ of state forest, 244 ha of mangrove forest and 5,333 ha of community forest. Land area according to usage in Nusa Penida is presented in Table 2. 
Table 3. Land Area According to Usage in Nusa Penida in 2017 (Ha)

\begin{tabular}{|l|l|c|}
\hline No & \multicolumn{1}{|c|}{ Land Use } & Land \\
\hline 1 & Agricultural Land & 14.366 \\
\hline 1.1 & Rice field land & \\
\hline a. & Irigation & - \\
\hline b. & Rainfed & - \\
\hline c. & Tidal Swamp & - \\
\hline d. & Swamp Lebak & 14,366 \\
\hline 1.2 & Not Paddy Field & 4,970 \\
\hline a. & Tegal / Kebun & - \\
\hline b. & Field / Huma & 3,572 \\
\hline c. & Plantation & 5,361 \\
\hline d. & Planted Trees & - \\
\hline f. & Pasture & - \\
\hline g. & Temporary Land Not Cultivated & 6,381 \\
\hline 2. & Land Not Agriculture & 824 \\
\hline a. & State Forest $\quad$ Total & 224 \\
\hline b. & Mangrove $\quad 20,284$ \\
\hline c. & Community Forest & $\mathbf{2 0 , 3 3 3}$ \\
\hline & &
\end{tabular}

Source: Klungkung in Figures 2018

\section{- Land Capabilty}

Land capability is a systematic land appraisal based on traits that are potential and a barrier to its sustainable use. Land capability analysis, including analysis of soil properties (physical and chemical), topography, drainage, soil depth, and other environmental conditions. Based on the characteristics of the land, a land capability classification with depth of class, sub-class and management unit is carried out. Land capability is closely related to "the level of danger of damage" and "obstacles in managing land". The land capability classification is grouped into 8 classes, from class I to class VIII. In this case, if the level of danger / risk of damage and barriers to use increase, the spectrum of land use decreases. The land capability class is divided into VIII classes. From classes I to IV can be used for agriculture, while from classes V to VII for pasture, class VIII should naturally be protected forest. Each class is further divided into sub-classes, namely the erosion sub-class, waterlogging sub-class, solum sub-class (rooting inhibitor) and climate sub-class. Subclasses can be divided again into several units of land class classification and their use can be seen in Table 4 and land capability classes and their limiting factors in Nusa Penida can be seen in Table 5.

Table 4 Classification of Land Capabilities in Class Level

\begin{tabular}{|c|l|l|}
\hline Class & \multicolumn{1}{|c|}{ Criteria } & \multicolumn{1}{|c|}{ Usage } \\
\hline I & $\begin{array}{l}\text { Does not have or only a few obstacles that limit its use. } \\
\text { Suitable for various uses, especially agriculture. } \\
\text { Characteristics of the land include: almost flat } \\
\text { topography, the threat of small erosion, deep effective } \\
\text { depth, good drainage, easy to process, good water } \\
\text { holding capacity, fertile, not threatened by flood }\end{array}$ & $\begin{array}{l}\text { Agriculture: } \\
\text { Agricultural crops annuals. } \\
\text { Grass plants. } \\
\text { Forests and nature reserves. }\end{array}$ \\
\hline II & $\begin{array}{l}\text { Has several obstacles or threats of damage that reduce } \\
\text { the choice of use or require moderate conservation } \\
\text { action. } \\
\text { Management needs to be careful, including conservation } \\
\text { measures to prevent damage. }\end{array}$ & $\begin{array}{l}\text { Agriculture: } \\
\text { a. Annual crops. } \\
\text { b. Grass plants. } \\
\text { c. Pasture. } \\
\text { d. Production forest. } \\
\text { e. Protected forest. } \\
\text { f. Nature preserve. }\end{array}$ \\
\hline III & Has several obstacles which reduce land use choices and & Agriculture: \\
\hline
\end{tabular}




\begin{tabular}{|c|c|c|}
\hline & $\begin{array}{l}\text { require special conservation measures and both. } \\
\text { Has a more severe barrier than class II and if used for } \\
\text { plants need soil management and more difficult } \\
\text { conservation measures to implement. } \\
\text { The obstacles in number I limit the use of annual crops, } \\
\text { processing time, choice of plants or combination of these } \\
\text { constraints. }\end{array}$ & $\begin{array}{l}\text { Annual crops. } \\
\text { Plants that require tillage. } \\
\text { Grass plants. } \\
\text { Meadow. } \\
\text { Production forest. } \\
\text { Protected forest and nature } \\
\text { reserve. }\end{array}$ \\
\hline IV & $\begin{array}{l}\text { Obstacles and threats of soil damage are greater than } \\
\text { class III, and crop choices are also limited. } \\
\text { Careful management of annual crops is needed, } \\
\text { conservation measures are more difficult to implement. }\end{array}$ & $\begin{array}{l}\text { 1. Agriculture: } \\
\text { Annual crops. } \\
\text { Plants that require tillage. } \\
\text { Grass plants. } \\
\text { Meadow. } \\
\text { Production forest. } \\
\text { Protected forest and nature } \\
\text { reserve. } \\
\text { 2. Non-Agriculture }\end{array}$ \\
\hline V & $\begin{array}{l}\text { Not threatened by erosion but has other obstacles that are } \\
\text { not easy to remove, thus limiting the choice of use. } \\
\text { Has obstacles that limit the choice of use and plants } \\
\text { types. } \\
\text { Located on a flat topography - almost flat but often } \\
\text { affected by flooding, rocky or inadequate climate. }\end{array}$ & $\begin{array}{l}\text { 1. Agriculture: } \\
\text { Grass plants. } \\
\text { Pasture. } \\
\text { Production forest. } \\
\text { Protected forest and natural } \\
\text { asylum. } \\
\text { 2. Non-agriculture }\end{array}$ \\
\hline VI & $\begin{array}{l}\text { Has a severe inhibiting factor that causes the land use is } \\
\text { very limited because it has the threat of damage that } \\
\text { cannot be eliminated. } \\
\text { Generally located on steep slopes, so that if used for } \\
\text { grazing and production forests must be managed properly } \\
\text { to avoid erosion. }\end{array}$ & $\begin{array}{l}\text { 1. Agriculture: } \\
\text { Grass plants. } \\
\text { Pasture. } \\
\text { Production forest. } \\
\text { Protected forest and nature } \\
\text { reserve } \\
\text { 2. Non-agriculture }\end{array}$ \\
\hline VII & $\begin{array}{l}\text { Has inhibiting factors and severe threats that cannot be } \\
\text { eliminated, therefore their use must be on a conservation } \\
\text { nature. If used for pasture or production forest, heavy } \\
\text { erosion prevention must be done. }\end{array}$ & $\begin{array}{l}\text { a. Meadow. } \\
\text { b. Production forest }\end{array}$ \\
\hline VIII & $\begin{array}{l}\text { It should be left naturally. } \\
\text { Barriers and threats are very severe and conservation } \\
\text { measures are not possible, so they need to be protected }\end{array}$ & $\begin{array}{l}\text { a. Protected forest. } \\
\text { b. Nature recreation. } \\
\text { c. Nature preserve }\end{array}$ \\
\hline
\end{tabular}

Table 5 Land Capability Class and Limitation Factors in Nusa Penida

\begin{tabular}{|c|c|l|r|r|}
\hline No & Land Capability & \multicolumn{1}{|c|}{ Limitation Factors } & \multicolumn{2}{|c|}{ Area } \\
\cline { 3 - 5 } & Class & \multicolumn{1}{|c|}{ Ha } & \multicolumn{1}{c|}{$\%$} \\
\hline 1 & I & \multicolumn{1}{|c}{-} & 0 & 0 \\
\hline 2 & II & Slope 3 - 8\% & 216 & 1.06 \\
\hline 3 & III & $\begin{array}{l}\text { Slope 8-15\%, soil depth 50-90 cm, } \\
\text { texture is rather rough }\end{array}$ & 4,577 & 22.56 \\
\hline 4 & IV & Slope 15-30\% & 4,222 & 20.81 \\
\hline 5 & V & Bad drainage & 224 & 1.10 \\
\hline 6 & VI & $\begin{array}{l}\text { Slope rather steep 30-45\%, heavy } \\
\text { erosion, soil depth <30 cm }\end{array}$ & 6,686 & 32.96 \\
\hline 7 & VII & $\begin{array}{l}\text { 45-65\% steep slope, very heavy } \\
\text { erosion }\end{array}$ & 1,737 & 8.56 \\
\hline 8 & VIII & Very steep slopes> 65\% & 2,622 & 12.93 \\
\hline & \multicolumn{1}{|c|}{ Total } & $\mathbf{2 0 , 2 8 4}$ & $\mathbf{1 0 0}$ \\
\hline
\end{tabular}




\section{- Land Availability}

Calculation of land availability is carried out based on Minister of the Environment Regulation No. 17 in 2009 concerning on The Guidelines for Determination of Environmental Support Capacity in Regional Spatial Planning. Based on this, the data needed in the calculation of land availability are the actual production of each type of commodity $(\mathrm{Pi})$ and the price of rice at the producer level $(\mathrm{Hb})$, the unit price of each commodity at the producer level (Hi), and the productivity of rice in Nusa Penida (Ptvb). The calculation of the total production value of each commodity in Nusa Penida is presented in Table 6 as follows:

Table 6. Results of Calculation of Total Production Value in Nusa Penida in 2017

\begin{tabular}{|r|l|r|r|r|}
\hline No & \multicolumn{1}{|c|}{$\begin{array}{c}\text { Commodity } \\
\text { type }\end{array}$} & $\begin{array}{c}\text { Actual } \\
\text { Production(Pi) } \\
\text { (Kg) }\end{array}$ & $\begin{array}{c}\text { Unit Price } \\
\text { of Commodity (Hi) } \\
\text { (Rp/Kg) }\end{array}$ & \multicolumn{1}{c|}{$\begin{array}{c}\text { Production Value } \\
\text { (PixHi) } \\
\text { (Rp) }\end{array}$} \\
\hline 1 & Corn & $9,334,000$ & 4,600 & $42,936,400,000$ \\
\hline 2 & Cassava & $16,344,000$ & 3,800 & $62,107,200,000$ \\
\hline 3 & Peanuts & $1,103,000$ & 8,000 & $8,824,000,000$ \\
\hline 4 & Green Beans & 43,000 & 10,000 & $430,000,000$ \\
\hline 5 & Red Beans & 63,000 & 12,000 & $756,000,000$ \\
\hline 6 & Undis & 38,000 & 15,000 & $570,000,000$ \\
\hline 7 & Mango & $3,500,000$ & 7,000 & $24,500,000,000$ \\
\hline 8 & Siam Orange & 94,000 & 8,000 & $752,000,000$ \\
\hline 9 & Water Guava & 3,600 & 6,500 & $23,400,000$ \\
\hline 10 & Sapodilla & 13,200 & 12,000 & $158,400,000$ \\
\hline 11 & Pineapple & 500 & 5,000 & $2,500,000$ \\
\hline 12 & Silik & 4,000 & 8,000 & $3,200,000$ \\
\hline 13 & Papaya & 16,700 & 5,000 & $83,500,000$ \\
\hline 14 & Banana & 501,700 & 10,000 & $5,017,000,000$ \\
\hline 15 & Guava & 6,200 & 8,000 & $49,600,000$ \\
\hline 16 & Jackfruit & 26,900 & 5,500 & $147,950,000$ \\
\hline 17 & Coconut & 329,000 & 4,000 & $1,316,000,000$ \\
\hline 18 & Cashew nuts & 58,950 & 25,000 & $1,473,750,000$ \\
\hline 19 & Cow & 24,192 & $9,500,000$ & $229,824,000,000$ \\
\hline 20 & Goat & 224 & $3,000,000$ & $672,000,000$ \\
\hline 21 & Pig & 13,283 & $2,000,000$ & $26,566,000,000$ \\
\hline 22 & Chicken & 119,134 & 80,000 & $9,530,720,000$ \\
\hline & & & & $\mathbf{3 9 7 , 0 2 9 , 1 8 0 , 0 0 0}$ \\
\hline
\end{tabular}

Source: Nusa Penida in Figures 2018 and survey results

Based on data from the Central Statistics Agency combined with the results of the survey unit price of rice at the producer level of Rp9,200 per kilogram and the average rice production per hectare is 7,900 kilograms per hectare, the availability of land in Nusa Penida is 5,462.7 hectares.

\section{- Land requirements}

Land requirement is minimum living needs. Population pressure on the carrying capacity of land can be determined based on a comparative value between the population and the percentage of farmers with a minimum area of land to live properly (Soermarwoto, 2001). The area of land needed for the needs of decent living per population is the need for a decent living per population divided by the productivity of local rice. According to Minister of the Environment Regulation No. 17 in 2009, it is assumed that 1 ton of rice / capita / year is equivalent to the standard of living needs per population. As is known above, rice productivity in Nusa Penida District is $2,400 \mathrm{~kg} / \mathrm{ha} /$ year. So the area of land needed for decent living needs per population in Nusa Penida is 0.417 hectares / person.

The calculation of land requirements in Nusa Penida uses the approach of population in Nusa Penida and the number of tourists each year who travel to Nusa Penida. Based on data from the National Tourism Strategic 
Area study, the number of tourists coming to Nusa Penida in 2015 was 255,079 people, in 2016 was 293,647 people and in 2017 was338,046 people. Using basic data in 2016, the rate of tourist growth was $15.12 \%$. Projected tourist arrivals can be seen in Table 7.

Table 7. Projection of Tourists Arrival in Nusa Penida

\begin{tabular}{|c|c|c|}
\hline No & Year & $\begin{array}{c}\text { Tourists Arrival } \\
\text { Projection }\end{array}$ \\
\hline 1 & 2018 & 389,159 \\
\hline 2 & 2019 & 447,999 \\
\hline 3 & 2020 & 515,737 \\
\hline 4 & 2021 & 593,716 \\
\hline 5 & 2022 & 683,486 \\
\hline 6 & 2023 & 786,829 \\
\hline 7 & 2024 & 905,798 \\
\hline 8 & 2025 & $1,042,754$ \\
\hline 9 & 2026 & $1,200,419$ \\
\hline 10 & 2027 & $1,381,922$ \\
\hline 11 & 2028 & $1,590,869$ \\
\hline
\end{tabular}

Source: KSPN Nusa Penida and Projection Results

The average number of tourists staying in the Nusa Penida Tourism Area is 3 days, then the projection of the number of tourists staying for 1 year in the Nusa Penida Tourism Area can be seen in Table 8.

Table 8. Projection of the Number of Tourist Who Stayed for 1 Year in Nusa Penida

\begin{tabular}{|c|c|c|}
\hline No & Year & $\begin{array}{c}\text { Projection of Tourists Staying for } \\
\text { 1 Year in Nusa Penida }\end{array}$ \\
\hline 1 & 2018 & 3,199 \\
\hline 2 & 2019 & 3,682 \\
\hline 3 & 2020 & 4,239 \\
\hline 4 & 2021 & 4,880 \\
\hline 5 & 2022 & 5,618 \\
\hline 6 & 2023 & 6,467 \\
\hline 7 & 2024 & 7,445 \\
\hline 8 & 2025 & 8,571 \\
\hline 9 & 2026 & 9,866 \\
\hline 10 & 2027 & 11,358 \\
\hline 11 & 2028 & 13,076 \\
\hline
\end{tabular}

Source: KSPN Nusa Penida and Projection Results

From the projected number of tourists staying for 1 year in Nusa Penida categorized as residents, thus the number of residents in Nusa Penida will be the original population of Nusa Penida plus the number of tourists staying for 1 year in Nusa Penida as presented in Table 9.

Table 9. Projections of Population + Tourists in Nusa Penida

\begin{tabular}{|c|c|c|c|c|}
\hline No & Year & $\begin{array}{c}\text { Number of } \\
\text { Population } \\
\text { Projection }\end{array}$ & $\begin{array}{c}\text { Number of } \\
\text { Tourists } \\
\text { Projection }\end{array}$ & Total \\
\hline 1 & 2018 & 45,510 & 3,199 & 48,709 \\
\hline 2 & 2019 & 45,560 & 3,682 & 49,242 \\
\hline 3 & 2020 & 45,610 & 4,239 & 49,849 \\
\hline 4 & 2021 & 45,660 & 4,880 & 50,540 \\
\hline 5 & 2022 & 45,711 & 5,618 & 51,328 \\
\hline 6 & 2023 & 45,761 & 6,467 & 52,228 \\
\hline 7 & 2024 & 45,811 & 7,445 & 53,256 \\
\hline
\end{tabular}




\begin{tabular}{|c|c|c|c|c|}
\hline 8 & 2025 & 45,862 & 8,571 & 54,432 \\
\hline 9 & 2026 & 45,912 & 9,866 & 55,778 \\
\hline 10 & 2027 & 45,963 & 11,358 & 57,321 \\
\hline 11 & 2028 & 46,013 & 13,076 & 59,089 \\
\hline
\end{tabular}

Source: BPS Data, KSPN Nusa Penida and Projection Results

Based on the projected population + tourists in Nusa Penida and the area of land needed for decent living needs per resident in Nusa Penida, the land needs in Nusa Penida are presented in Table 10.

Table 10. Land Requirement Projection in Nusa Penida

\begin{tabular}{|c|c|c|}
\hline No & Year & $\begin{array}{c}\text { Land Requirement } \\
\text { Projection in Nusa Penida } \\
\text { (ha) }\end{array}$ \\
\hline 1 & 2018 & 20,311 \\
\hline 2 & 2019 & 20,534 \\
\hline 3 & 2020 & 20,787 \\
\hline 4 & 2021 & 21,075 \\
\hline 5 & 2022 & 21,404 \\
\hline 6 & 2023 & 21,779 \\
\hline 7 & 2024 & 22,208 \\
\hline 8 & 2025 & 22,698 \\
\hline 9 & 2026 & 23,260 \\
\hline 10 & 2027 & 23,903 \\
\hline 11 & 2028 & 24,640 \\
\hline
\end{tabular}

Source: Projection Calculation Results

\section{- Land carrying capacity status}

The carrying capacity of land is obtained from the comparison between land availability (S L) and land needs (DL). Based on Table 11 regarding the projected land requirements and land availability in Nusa Penida, which is 5,462.7 hectares, the carrying capacity of the land in Nusa Penida is deficit or exceeded because the availability of land is less than the land requirement.

2. Land Carrying Capacity based on Ecological Footprint

Calculation of the ecological footprint requires consumption data or the needs of each type of primary product which can be either primary primary products or secondary primary products. Data on consumption or needs of each type of primary product that can be either primary primary products or secondary primary products in Nusa Penida can be seen in Table 11.

Table 11. Consumption Data or Needs of Each Main Type of Product in Nusa Penida

\begin{tabular}{|l|l|c|c|c|}
\hline No & \multicolumn{1}{|c|}{ Commodity } & $\begin{array}{c}\text { Consumption } \\
\text { (kg/capita/year) }\end{array}$ & $\begin{array}{c}\text { Number of } \\
\text { Population }\end{array}$ & $\begin{array}{c}\text { Total } \\
\text { Consumption } \\
\text { (Ton) }\end{array}$ \\
\hline Agriculture & & & \\
\hline 1 & Rice & 100.57 & 47,957 & $4,823.035$ \\
\hline 2 & Wheat & 2.35 & 47,957 & 112.699 \\
\hline 3 & Soybean & 4.97 & 47,957 & 238.3463 \\
\hline 4 & Sugar & 24.7 & 47,957 & $1,184.538$ \\
\hline 5 & Frying Oil & 11.78 & 47,957 & 564.9335 \\
\hline 6 & Vegetable & 52.33 & 47,957 & $2,509.59$ \\
\hline Livestock & & & \\
\hline 10 & Beef & 0.42 & 47,957 & 20.14194 \\
\hline 11 & Chicken meat & 5.37 & 47,957 & 257.5291 \\
\hline 12 & Fork & 0.26 & 47,957 & 12.46882 \\
\hline 13 & Egg & 9.79 & 47,957 & 469.499 \\
\hline
\end{tabular}




\begin{tabular}{|l|l|c|c|c|}
\hline 14 & Milk & 6.17 & 47,957 & 295.8947 \\
\hline Forest & & Volume $\mathbf{( m}^{\mathbf{3}}$ & & \\
\hline 15 & Wood & 0.19481 & 47,957 & $9,342.503$ \\
\hline Fishery & 31.17 & 47,957 & $1,494.82$ \\
\hline Built Area & Width (Ha) & & \\
\hline 16 & $\begin{array}{l}\text { Settlement and } \\
\text { Industry }\end{array}$ & 845.721 & & \\
\hline 17 & Transportation & 124.665 & & \\
\hline Energy Use & & $\begin{array}{c}\text { Consumption Net } \mathbf{( 1 0}^{\mathbf{3}} \\
\text { t) }\end{array}$ & & \\
\hline 18 & Kerosene & 0.000054108 & 47,957 & 2,5949 \\
\hline 19 & Diesel oil & 0.000043894 & 47,957 & 2,1050 \\
\hline 20 & Petrol & 0.000141600 & 47,957 & 6,7907 \\
\hline 21 & Gas & 0.018396741 & 47,957 & 882.2525 \\
\hline 22 & Electricity & 0.698210431 & 47,957 & $33,484.0777$ \\
\hline
\end{tabular}

Average per capita consumption for agricultural, livestock and fishery products uses Ministry of Agriculture Statistics data for 2017. The average wood consumption system uses the timber consumption approach conducted by Siagian in 1992. The built area data comes from the digitization results of Nusa Penida District map. Meanwhile the energy consumption data uses data sources from each of the Bali Province Regional Organization and PLN data. The calculation of the ecological footprint based on the six parts of basic needs products expressed in the form of agricultural, livestock, forest, fishery products, built up areas, and energy use in Nusa Penida can be seen in Table 12.

Table 12. Calculation of the Ecological Footprint in Nusa Penida

\begin{tabular}{|l|c|c|c|c|}
\hline \multicolumn{1}{|c|}{ Basic Product } & $\begin{array}{c}\text { Total } \\
\text { Consumption }\end{array}$ & $\begin{array}{c}\text { Global yield } \\
\text { (t/ha) }\end{array}$ & $\begin{array}{c}\text { Equivalent } \\
\text { Factor } \\
\text { (gha/ha) }\end{array}$ & JE (gha/cap) \\
\hline Agriculture & & & & \\
\hline Rice & $4,823.035$ & 2.80 & 2.64 & 0.094823133 \\
\hline Wheat & 112.699 & 4.11 & 2.64 & 0.002215715 \\
\hline Soybean & 238.3463 & 47.07 & 2.64 & 0.004686000 \\
\hline Sugar & $1,184.538$ & 2.83 & 2.64 & 0.023288573 \\
\hline Frying Oil & 564,9335 & 2.38 & 2.64 & 0.011106858 \\
\hline Vegetable & $2,509.59$ & 16.92 & 2.64 & 0.049339718 \\
\hline Livestock & & & & \\
\hline Beef & 20.14194 & 2.23 & 0.50 & 0.000075000 \\
\hline Chicken meat & 257.5291 & 2.23 & 0.50 & 0.000958929 \\
\hline Egg & 12.46882 & 2.23 & 0.50 & 0.000046429 \\
\hline Milk & 469.499 & 2.23 & 0.50 & 0.001748214 \\
\hline Forest & & & & \\
\hline Wood & $9,342.503$ & 1.84 & 1.33 & 0.092534748 \\
\hline Fishery & $1,494.82$ & 19.15 & 0.40 & 0.004452858 \\
\hline Built Area & & & & \\
\hline $\begin{array}{l}\text { Settlement } \\
\text { Industry }\end{array}$ & 845.721 & 1.74 & 2.64 & 0.081008069 \\
\hline Transportation & 124.665 & 1.74 & 2.64 & 0.002450972 \\
\hline Energy Use & & & & \\
\hline Kerosene & 2,5949 & 0.27 & 1.35 & 0.000165574 \\
\hline Diesel oil & 2,1050 & 0.27 & 1.35 & 0.00000053 \\
\hline Petrol & 6,7907 & 0.27 & 1.35 & 0.00054706 \\
\hline Gas & 882.2525 & 0.27 & 1.35 & 0.00000563 \\
\hline
\end{tabular}




\begin{tabular}{|l|l|l|l|l|}
\hline Electricity & $33,484.0777$ & 0.27 & 1.35 & 0.00013301 \\
\hline
\end{tabular}

The results of the calculation of land requirements based on the ecological footprint amounted to 17,724.283 hectares, while the availability of land in Nusa Penida was 5,350 hectares. This shows that the carrying capacity of the land in Nusa Penida has a deficit of 12.374,283 hectares. With this condition, preventive steps are needed thus the carrying capacity of the land remains sustainable and the environment in Nusa Penida is sustainable.

\section{Water resources river}

Nusa Penida's topographical characteristics consist of hills and valleys but no perennial rivers are found which are permanent streams. In general, rivers in Nusa Penida only flow during the rainy season, especially when it rains and after rain falls, so that the potency of river water in this area cannot be used for irrigation needs and the provision of clean water for its residents. Based on research by the Regional Office of Public Works in Bali Province (1994), the potential for the flow of rivers on Nusa Penida Island annually is 24 million $\mathrm{m} 3$. The rivers on the island of Nusa Penida are included in the river with the category of having less condition, which are always lacking water every year.

\section{- Water springs}

There are 16 springs in Nusa Penida, mostly near the coast in the southern coastal region. Whereas the concentration of the population on this island is mostly along the north coast, so as to obtain water sources from these springs it experiences obstacles, especially the distance which is quite far and the area is hilly. Although in terms of numbers are quite a lot, but not all springs are potency to be used (Department of Public Works, 2008).

Based on the report from the Department of Public Works, only a part of the springs identified in Nusa Penida could be identified. These springs ranges from 0.5 to $2001 /$ second (Table 13). Of the eight identified springs potency, there are two springs whose discharge is relatively large, namely Penida springs in Sakti Village with a discharge of 200 litre / second and Peguyangan in Batukandik Village with a discharge of 178.4 litre / second. Meanwhile, in Nusa Lembongan and Nusa Ceningan there are no springs (Department of Public Works, 2008).

Table 13. Water Springs Potency in Nusa Penida

\begin{tabular}{|c|l|c|}
\hline No & \multicolumn{1}{|c|}{ Location } & Potensi (1/dt) \\
\hline 1 & Water Springs Penida -Sakti Village & 200 \\
\hline 2 & Water Springs Seganing - Bungamekar Village & 78,8 \\
\hline 3 & Water Springs Temeling - Batumadeg Village & 26,4 \\
\hline 4 & Water Springs Peguyangan - Batukandik Village & 178,4 \\
\hline 5 & Water Springs Tabuanan - Sekartaji Village & 38,5 \\
\hline 6 & Water Springs Anceng - Sekartaji Village & 1,25 \\
\hline 7 & Water Springs Wates - Tanglad Village & 0,75 \\
\hline 8 & Water Springs Angkal - Suana Village & 0,50 \\
\hline & Total & $\mathbf{5 2 4 , 6 0}$ \\
\hline
\end{tabular}

Source: PU Department (2008).

Water springs in Nusa Penida region have different potency and the distribution is not the same. The capacity of the spring is very dependent on hydrological conditions, climate, catchment area, vegetation, and geological structure. Currently, of the 9 (nine) springs, there are 2 (two) springs that have been managed (built clean water network) by the PDAM, namely Penida Water Springs (discharge rate $=+200 \mathrm{lt} / \mathrm{sec}$ ) and Guyangan Water Springs (large debit $=+178 \mathrm{lt} / \mathrm{sec}$ ). Both of these springs have been used as drinking water sources by the PDAM of Klungkung Regency, but the utilization of the two springs is currently not optimal due to high operational costs.

\section{- Groundwater}

Ground water is water that is below the surface of the land. Groundwater potential is very much determined by its lithology conditions. Based on the Bali Island Groundwater Basin Distribution Map (Geological Agency, 2008), in the Klungkung Regency area there are two Groundwater Basins namely the Denpasar- 
Tabanan and the Nusa Penida. Nusa Penida Groundwater Basins has a total free ground water recharge of 39 million $\mathrm{m}^{3} /$ year and without the potential for depressed ground water recharge.

In Nusa Penida Island, groundwater drilling has been carried out by the Bali Province Groundwater Development Project (P2AT) and the Bali Tourism Development Corporation (BTDC) with a depth of between 30-108 m. The groundwater potential has been managed by the Nusa Penida PDAM (through a wellbore) in a limited way, in the Village of Kutampi.

Two drill wells in Kutampi Village are located close to each other and the depth of the well reaches $45 \mathrm{~m}$. The installed capacity and drainage of each wellbore are $2.5 \mathrm{lt} / \mathrm{sec}$. The transmission pipe used is galvanized pipe, $100 \mathrm{~mm}$ in diameter and accommodated in a reservoir capacity of $200 \mathrm{~m}^{3}$ before being distributed to the community. Distribution pipes use PVC pipes with diameters between $50 \mathrm{~mm}-200 \mathrm{~mm}$ with service areas including: Desa Kutampi, Batununggul, Ped, and Toyapakeh. But unfortunately this Kutampi artesian well is not good water quality.

The potential for ground water on Nusa Lembongan Island has been managed by the Nusa Penida PDAM (through bore wells) in a limited manner with sufficiently good water quality so that it can serve and supply the clean water needs of the people on Nusa Ceningan and Nusa Lembongan Islands. Based on an inventory of groundwater potential through a Geoelectric Study using secondary data located in the Village of Jungut Batu (around well-3), it can be concluded that "no indication of a layer containing fresh water" was found.

\section{- Carrying Capacity of the Environment based on Water Availability}

Water carrying capacity of an area is "the ratio between the availability and demand of water" in the area concerned. The approach used in determining the carrying capacity of water is to use the runoff coefficient method based on land use data, and annual rainfall data. While water needs are calculated from the results of the conversion of the need for a decent living population for water which is determined by the size of the human population in an area. Referring to Minister of Environment Regulation No. 17 of 2009 year concerning the Guidelines for Determination of Environmental Carrying Capacity in Spatial Planning has provided a constant number about the level of water consumption that comes from the level of consumption of water for basic needs such as rice, eggs, and fruit that is synchronized with water needs and also from the utilization of virtual water to produce one unit of product.

The availability (supply) of water, in relation to the carrying capacity of water, is the amount of water reserves available to meet the daily needs of human life (domestic needs) and human needs for water to produce one unit of product within a period of 1 (one) year. The availability of water is sourced from surface water such as river water and underground water, which in principle all come from rain water. The level of water availability in an area is influenced by 3 (three) factors namely; rainfall, weighted runoff coefficient, and area. Whereas the demand for water, in relation to the carrying capacity of water, is an illustration of the amount of water needed for the daily needs of human life (domestic needs) and human needs for water to produce one unit of product within a period of 1 (one) year.

\section{Water Availability}

The results of runoff coefficient analysis revealed that 4,970 ha $(24.5 \%)$ of tegal / garden land in Nusa Penida had runoff coefficient value of $0.3,3,572$ ha $(17.61 \%)$ of plantation land had runoff coefficient of 0.52 , covering an area of 5,361 ha $(26.4 \%)$ planted with trees have a runoff coefficient value of 0.3 , an area of 824 ha $(4.1 \%)$ is a State forest with a runoff coefficient value of 0.18, 224 ha $(1.1 \%)$ is a mangrove forest with runoff coefficient value of 0.3 and an area of 5,333 is community forest with runoff coefficient value of 0.3 .

Table 14. Runoff Coefficient Value for Each Type of Land Use in Nusa Penida

\begin{tabular}{|l|l|c|c|c|}
\hline No & \multicolumn{1}{|c|}{ Land Use } & $\begin{array}{c}\text { Land Area } \\
\text { (Ai) }\end{array}$ & $\begin{array}{c}\text { Rauoff } \\
\text { Coefficient } \\
\text { (Ci) }\end{array}$ & (Ai x Ci) \\
\hline 1 & Agricultural Land & 14,366 & & \\
\hline 1.1 & Paddy Fields & & & \\
\hline a. & Irrigation & & & \\
\hline b. & Rainfed & - & & \\
\hline c. & Tidal Swamp & - & & \\
\hline
\end{tabular}




\begin{tabular}{|c|c|c|c|c|}
\hline d. & Swamp & - & & \\
\hline 1.2 & Not Paddy Field & 14,366 & & \\
\hline a. & Garden & 4,970 & 0.3 & 1,491 \\
\hline b. & Field & - & & \\
\hline c. & Plantation & 3,572 & 0.52 & $1,857.44$ \\
\hline d. & Planted Trees & 5,361 & 0.3 & $1,608.3$ \\
\hline f. & Pasture & - & & \\
\hline g. & Temporary Land Not Cultivated & - & & \\
\hline 2. & Land Not Agriculture & 6,381 & & \\
\hline a. & State Forest & 824 & 0.18 & 148.32 \\
\hline b. & Mangrove & 224 & 0.3 & 67.2 \\
\hline c. & Community Forest & 5,333 & 0.3 & $1,599.9$ \\
\hline & Total & 20,284 & & $6,772.16$ \\
\hline
\end{tabular}

Based on the calculations set out in the table above, the weighted runoff coefficient value in Nusa Penida is 0.33 . The average annual rainfall in Nusa Penida over the past 10 years is $1428.40 \mathrm{~mm}$. The data was obtained from the results of the Geographic Information System (GIS) analysis using the Kriging Interpolation Method. The availability of water in Nusa Penida is divided into three patterns as follows:

a) The availability of water based on rainfall alone is $95,443,402.56 \mathrm{~m} 3 /$ year.

b) Water availability is based on $10 \%$ of Peguyangan and Penida springs usage of 2,528,408,256.44 $\mathrm{m}^{3} /$ year.

c) Availability of water based on rainfall $+10 \%$ of Peguyangan and Penida springs usage is $2,623,851,659$ $\mathrm{m}^{3} /$ year.

d) Availability of water based on rainfall is added to all springs in Nusa Penida if used $100 \%$. So the availability of water is $35,052,932,640 \mathrm{~m}^{3} /$ year.

\section{Water needs}

The level of water demand is determined by the number of population / population in this case the population of Nusa Penida plus tourists in 1 year of stay in Nusa Penida. Projected water needs in Nusa Penida are presented in Table 15.

Table 15. Projection of Water Needs in Nusa Penida

\begin{tabular}{|c|c|c|c|c|c|}
\hline No & Year & $\begin{array}{c}\text { Projection of } \\
\text { Total } \\
\text { Population }\end{array}$ & $\begin{array}{c}\text { Projection of } \\
\text { Total } \\
\text { Traveler }\end{array}$ & Total & $\begin{array}{c}\text { Projection Water } \\
\text { of Needs } \\
\text { ( m } \mathbf{3} / \text { tahun })\end{array}$ \\
\hline 1 & 2018 & 45,510 & 3,199 & 48,709 & 77,934400 \\
\hline 2 & 2019 & 45,560 & 3,682 & 49,242 & 78,787200 \\
\hline 3 & 2020 & 45,610 & 4,239 & 49,849 & 79.758400 \\
\hline 4 & 2021 & 45,660 & 4,880 & 50,540 & 80,864000 \\
\hline 5 & 2022 & 45,711 & 5,618 & 51,328 & 82,124800 \\
\hline 6 & 2023 & 45,761 & 6,467 & 52,228 & 83,564800 \\
\hline 7 & 2024 & 45,811 & 7,445 & 53,256 & 85,209600 \\
\hline 8 & 2025 & 45,862 & 8,571 & 54,432 & 87,091200 \\
\hline 9 & 2026 & 45,912 & 9,866 & 55,778 & 89,244800 \\
\hline 10 & 2027 & 45,963 & 11,358 & 57,321 & 91,713600 \\
\hline 11 & 2028 & 46,013 & 13,076 & 59,089 & 94,542400 \\
\hline
\end{tabular}

\section{Water carrying capacity status}

Water carrying capacity comes from a comparison between the amount of water available and the level of water demand. Water carrying capacity status describes the ability of the environment (hydrosphere) in maintaining its condition due to human activities. Water carrying capacity status in Nusa Penida is surplus until 2023. Comparison of water demand and water availability is presented in Table 16 and water carrying capacity status in Nusa Penida is presented in Table 17.

Table 16. Comparison of Water Needs and water availability in Nusa Penida 


\begin{tabular}{|c|c|c|c|c|c|c|}
\hline No & Year & $\begin{array}{c}\text { Projection } \\
\text { of Water } \\
\text { Needs } \\
\left(\mathbf{m}^{\mathbf{3}} / \text { tahun }\right)\end{array}$ & $\begin{array}{c}\text { Rainfall } \\
\left(\mathbf{m}^{\mathbf{3}} / \text { tahun }\right)\end{array}$ & $\begin{array}{c}\mathbf{1 0 \%} \text { Water } \\
\text { Springs } \\
\text { Peguyangan and } \\
\text { Penida } \\
\left(\mathbf{m}^{\mathbf{3}} / \text { /tahun }\right)\end{array}$ & $\begin{array}{c}\text { Rainfall +10\% } \\
\text { Water Springs } \\
\text { Peguyangan } \\
\text { and Penida } \\
\left(\mathbf{m}^{\mathbf{3}} / \text { tahun }\right)\end{array}$ & $\begin{array}{c}\text { rainfal+all } \\
\text { water springs } \\
\left(\mathbf{m}^{\mathbf{3}} / \text { /tahun }\right)\end{array}$ \\
\hline 1 & 2018 & 77,934400 & $95,443,402.56$ & $2,528,408,256.44$ & $2,623,851,659$ & $35,052,932,640$ \\
\hline 2 & 2019 & 78,787200 & $95,443,402.56$ & $2,528,408,256.44$ & $2,623,851,659$ & $35,052,932,640$ \\
\hline 3 & 2020 & 79,758400 & $95,443,402.56$ & $2,528,408,256.44$ & $2,623,851,659$ & $35,052,932,640$ \\
\hline 4 & 2021 & 80,864000 & $95,443,402.56$ & $2,528,408,256.44$ & $2,623,851,659$ & $35,052,932,640$ \\
\hline 5 & 2022 & 82,124800 & $95,443,402.56$ & $2,528,408,256.44$ & $2,623,851,659$ & $35,052,932,640$ \\
\hline 6 & 2023 & 83,564800 & $95,443,402.56$ & $2,528,408,256.44$ & $2,623,851,659$ & $35,052,932,640$ \\
\hline 7 & 2024 & 85,209600 & $95,443,402.56$ & $2,528,408,256.44$ & $2,623,851,659$ & $35,052,932,640$ \\
\hline 8 & 2025 & 87,091200 & $95,443,402.56$ & $2,528,408,256.44$ & $2,623,851,659$ & $35,052,932,640$ \\
\hline 9 & 2026 & 89,244800 & $95,443,402.56$ & $2,528,408,256.44$ & $2,623,851,659$ & $35,052,932,640$ \\
\hline 10 & 2027 & 91,713600 & $95,443,402.56$ & $2,528,408,256.44$ & $2,623,851,659$ & $35,052,932,640$ \\
\hline 11 & 2028 & 94,542400 & $95,443,402.56$ & $2,528,408,256.44$ & $2,623,851,659$ & $35,052,932,640$ \\
\hline
\end{tabular}

Table 17 Projection of Water Carrying Capacity Status based of Rainfall and $10 \%$ Water Springs of Peguyangan and Penida in Nusa Penida

\begin{tabular}{|c|c|c|c|c|c|c|}
\hline \multirow[t]{2}{*}{ No } & \multirow[t]{2}{*}{ Year } & \multirow{2}{*}{$\begin{array}{c}\text { Projection } \\
\text { of Water } \\
\text { Needs } \\
\left(\mathbf{m}^{3} / \text { tahun) }\right.\end{array}$} & \multicolumn{2}{|c|}{ Status Daya Dukung } & \multicolumn{2}{|c|}{ Status Daya Dukung } \\
\hline & & & $\begin{array}{c}\text { Rainfall } \\
\left(\mathrm{m}^{3} / \text { tahun }\right)\end{array}$ & Surplus & $\begin{array}{c}10 \% \text { Water } \\
\text { Springs } \\
\text { Peguyangan and } \\
\text { Penida } \\
\left(\mathrm{m}^{3} / \text { tahun }\right)\end{array}$ & Surplus \\
\hline 1 & 2018 & 77,93 & $\begin{array}{c}95,443,402.5 \\
6\end{array}$ & $\begin{array}{c}17,509,002.5 \\
6\end{array}$ & $2,528,408,256.44$ & $\begin{array}{r}2,450,473,856.4 \\
4\end{array}$ \\
\hline 2 & 2019 & 78,787200 & $\begin{array}{c}95,443,402.5 \\
6\end{array}$ & $\begin{array}{c}16,656,202.5 \\
6\end{array}$ & $2,528,408,256.44$ & $\begin{array}{r}2,449,621,056.4 \\
4\end{array}$ \\
\hline 3 & 2020 & 79,758400 & $\begin{array}{c}95,443,402.5 \\
6\end{array}$ & $\begin{array}{c}15,685,002.5 \\
6\end{array}$ & $2,528,408,256.44$ & $\begin{array}{r}2,448,649,856.4 \\
4\end{array}$ \\
\hline 4 & 21 & 0 & $\begin{array}{c}95,443,402.5 \\
6\end{array}$ & $\begin{array}{c}14,579,402.5 \\
6\end{array}$ & 4 & $\begin{array}{r}2,447,544,256.4 \\
4 \\
\end{array}$ \\
\hline 5 & 2022 & 82,124800 & $\begin{array}{c}95,443,402.5 \\
6\end{array}$ & $\begin{array}{c}13,318,602.5 \\
6\end{array}$ & $2,528,408,256.44$ & $\begin{array}{r}2,446,283,456.4 \\
4\end{array}$ \\
\hline 6 & 2023 & 83,564800 & $\begin{array}{c}95,443,402.5 \\
6\end{array}$ & $\begin{array}{c}11,878,602.5 \\
6\end{array}$ & $2,528,408,256.44$ & $\begin{array}{r}2,444,843,456.4 \\
4\end{array}$ \\
\hline 7 & 2024 & 85,209600 & $\begin{array}{c}95,443,402.5 \\
6\end{array}$ & $\begin{array}{c}10,233,802.5 \\
6\end{array}$ & $2,528,408,256.44$ & $\begin{array}{r}2,443,198,656.4 \\
4 \\
\end{array}$ \\
\hline 8 & 2025 & 87,091200 & $\begin{array}{c}95,443,402.5 \\
6 \\
\end{array}$ & $8,352,202.56$ & $2,528,408,256.44$ & $\begin{array}{r}2,441,317,056.4 \\
4 \\
\end{array}$ \\
\hline 9 & 2026 & 89,244800 & $\begin{array}{c}95,443,402.5 \\
6\end{array}$ & $6,198,602.56$ & $2,528,408,256.44$ & $\begin{array}{r}2,439,163,456.4 \\
4\end{array}$ \\
\hline 10 & 2027 & 91,713600 & $\begin{array}{c}95,443,402.5 \\
6\end{array}$ & $3,72,9802.56$ & $2,528,408,256.44$ & $\begin{array}{r}2,436,694,656.4 \\
4 \\
\end{array}$ \\
\hline 11 & 2028 & 94,542400 & $\begin{array}{c}95,443,402.5 \\
6 \\
\end{array}$ & $901,002.56$ & $2,528,408,256.44$ & $\begin{array}{r}2,433,865,856.4 \\
4\end{array}$ \\
\hline
\end{tabular}

Table 18 Projection of Water Carrying Capacity Status based of Rainfall+ 10\% Water Springs of Peguyangan and Penida and Rainfall+all Water Springs in Nusa Penida

\begin{tabular}{|c|c|c|c|c|c|c|}
\hline No & Year & $\begin{array}{c}\text { Projection } \\
\text { of Water } \\
\text { Needs }\end{array}$ & \multicolumn{2}{|c|}{ Status Daya Dukung } & \multicolumn{2}{c}{ Status Daya Dukung } \\
\cline { 3 - 6 } & & Rainfall+10\% & Surplus & Rainfall+all & Surplus \\
\hline
\end{tabular}




\begin{tabular}{|c|c|c|c|c|c|c|}
\hline & & $\left(\mathrm{m}^{3} /\right.$ tahun $)$ & $\begin{array}{c}\text { Water Springs of } \\
\text { Peguyangan and } \\
\text { Penida } \\
\left(\mathrm{m}^{3} / \text { tahun }\right)\end{array}$ & & $\begin{array}{c}\text { Water Springs } \\
\left(\mathrm{m}^{3} / \text { tahun }\right)\end{array}$ & \\
\hline 1 & 2018 & 77,934400 & $2,623,851,659$ & $2,545,917,259$ & $\begin{array}{c}2,528,408,256.4 \\
4\end{array}$ & $\begin{array}{c}34,974,998,24 \\
0\end{array}$ \\
\hline 2 & 2019 & 78,787200 & $2,623,851,659$ & $2,545,064,459$ & $\begin{array}{c}2,528,408,256.4 \\
4\end{array}$ & $\begin{array}{c}34,974,145.44 \\
0\end{array}$ \\
\hline 3 & 2020 & 79,758400 & $2,623,851,659$ & $2,544,093,259$ & $\begin{array}{c}2,528,408,256.4 \\
4\end{array}$ & $\begin{array}{c}34,973,174,24 \\
0\end{array}$ \\
\hline 4 & 2021 & 80,864000 & $2,623,8$ &, 542, & $\begin{array}{c}2,528,408,256.4 \\
4\end{array}$ & $\begin{array}{c}34,972,068,64 \\
0\end{array}$ \\
\hline 5 & 2022 & 8 & 2,6 & 59 & $\begin{array}{c}2,528,408,256.4 \\
4\end{array}$ & $\begin{array}{c}34,970,807,84 \\
0\end{array}$ \\
\hline 6 & 2023 & 83,56 & $2,623,851,659$ & $2,540,286,859$ & $\begin{array}{c}2,528,408,256.4 \\
4\end{array}$ & $\begin{array}{c}34,969,367,84 \\
0\end{array}$ \\
\hline 7 & 2024 & 85,209600 & $2,623,851,659$ & 2,059 & $\begin{array}{c}2,528,408,256.4 \\
4\end{array}$ & $\begin{array}{c}34,967,723,04 \\
0\end{array}$ \\
\hline 8 & 2025 & 87,091200 & $2,623,851,659$ & $2,536,7604,59$ & $\begin{array}{c}2,528,408,256.4 \\
4\end{array}$ & $\begin{array}{c}34,965,841,44 \\
0 \\
\end{array}$ \\
\hline 9 & 2026 & 89,244800 & $2,623,851,659$ & $2,534,606,859$ & $\begin{array}{c}2,528,408,256.4 \\
4\end{array}$ & $\begin{array}{c}34,963,687,84 \\
0\end{array}$ \\
\hline 10 & 2027 & 91,713600 & $2,623,851,659$ & $2,532,138,059$ & $\begin{array}{c}2,528,408,256.4 \\
4\end{array}$ & $\begin{array}{c}34,961,219,04 \\
0\end{array}$ \\
\hline 11 & 2028 & 94,542400 & $2,623,851,659$ & $2,529,309,259$ & $\begin{array}{c}2,528,408,256.4 \\
4\end{array}$ & $\begin{array}{c}34,958,390,24 \\
0\end{array}$ \\
\hline
\end{tabular}

Even though the carrying capacity of water in Nusa Penida is in a surplus status, in reality most of the villages in this region are experiencing a water crisis. This is because surface water in the form of rainfall is accommodated in a body of water or a water storage facility, as well as existing ground water that is not affordable by residents to be utilized.

\section{Conclusion}

Based on the results of the research and discussion above the conclusions are drawn as follows:

1. The carrying capacity status of land in Nusa Penida has a high deficit and has been exceeded, where the ratio of land availability and land requirements is less than 1 or around 0.2 . The results of the calculation of land requirements based on the ecological footprint amounted to 17,724.283 hectares, while the availability of land in Nusa Penida was 5,350 hectares. This shows that the carrying capacity of land in Nusa Penida has exceeded the threshold or deficit is $12.374,283$ hectares.

2. The projected water carrying capacity status in Nusa Penida in 2018 is based on rainfall is surplus $17,509,002.56 \mathrm{~m}^{3} /$ year and in 2028 is surplus $901,002.56 \mathrm{~m}^{3} /$ year and in 2029 a deficit is estimated. The projection of the carrying capacity of water in Nusa Penida based on $10 \%$ utilization of springs Penida and Guyangan in 2018 is surplus of 2,450,473,856.44 $\mathrm{m}^{3} /$ year and in 2028 is surplus of $2,433,865,856.44 \mathrm{~m}^{3} / y e a r$. The projection of the carrying capacity of water in Nusa Penida based on rainfall $+10 \%$ utilization of springs Penida and Guyangan in 2018 is surplus of 2,545,917,259 $\mathrm{m}^{3} /$ year and in 2028 is surplus of 2,529,309,259 $\mathrm{m}^{3} /$ year. Projection of the carrying capacity of water in Nusa Penida based on rainfall + all potential springs in Nusa Penida in 2018 is surplus of $34,974,998,240 \mathrm{~m}^{3} /$ year and in 2028 is surplus of $34,958,390,240 \mathrm{~m}^{3} /$ year.

\section{Acknowledgment}

Thank you to the doctoral study program at the Udayana University, which has provided the opportunity to attend lectures, thanks also to the respondents and the Nusa Penida community who have helped in the 
implementation of this research. We present the results of this study to support environmental management efforts and support the advancement of tourism in Nusa Penida.

\section{References}

[1] Admadhani, D., N., Haji, A., T., S., Susanawati, L., D. 2014. Analysis of Water Supply and Needs for Environmental Support Capacity (Case Study of Malang City). Vol. 1. No. 3: PP 1320. Journal of Natural Resources and the Environment

[2] Asdak, C., Salim, H. 2006. Carrying Capacity of Water Resources as Spatial Planning Considerations; Vol. 7. No. 1: pp 16-22. Journal of Environmental Engineering P3TL-BPPT.

[3] BPS. 2015. Nusa Penida District in Figures. Semarapura

[4] Ministry of Public Works, 2008. Jakarta

[5] Bali Provincial Tourism Office, 2016. Nusa Penida National Tourism Strategic Area. Denpasar

[6] Lu, Y., Xu, H., Wang, Y., Yang, Y, 2017. Evaluation of water environmental carrying capacity of city in Huaihe River Basin based on the AHP method: A case in Huai'an City; Vol. 18: pp 7177. Water Resources and Industry.

[7] Moniaga, V., R., B. 2011. Analysis of the Carrying Capacity of Agricultural Land; Vol. 7. No. 3 : pp. 61-68. ASE.

[8] Minister of Environment Regulation No. 17 of 2009

[9] Pramesty, A., R., Nirmala, A., Aspan., A. 2014. Calculation of Environmental Support Capacity Based on Water Availability and Land Productivity in the Seven Belas District of Bengkayang Regency; Vol. 1. No. 1: pp 1-10. Journal of Wetland Environmental Technology.

[10] Qian, Y., Tang, T., Qiu, Q., Xu,T., Liao., J. 2015. A Comparative Analysis on Assessment of Land Carrying Capacity with Ecological Footprint Analysis and Index System Method: Xiamen. Chinese Academy of Sciences. Vol. 10. No. 6: pp 1-17.

[11] Riyadi, Supriyadi B. Deddy. 2004. Regional Development Planning: Strategy to Explore the Potential in Realizing Regional Autonomy. Gramedia Main Library. Jakarta.

[12] Santoso, D., H. 2015. Study of Water Carrying Capacity in Bintan Island, Riau Islands Province. Journal of Environmental Science and Technology. Vol 7. No. 1

[13] Soemarwoto, O. 2001. Ecology, Environment and Development. Delay: Jakarta.

[14] Sunarta, N. 2015. "The Impact of the Development of Accommodation Business on Water Resources in the North Kuta District of Badung Regency, Bali" (dissertation). Denpasar: Udayana University.

[15] Wijaya, H., Rusdiana., O., Tarigan, S., D. 2017. Environmental Supporting Capacity of Ciliwung Hulu Watershed, Bogor Regency; Vol. 2. No. 1; 25-32. Journal of Env. Engineering \& Waste Management 